\title{
The Demographics' Effects on Organizational Culture, Organizational Citizenship Behavior and Job Satisfaction: Evidence from Egypt and Mexico
}

\author{
Tarek A. El Badawy ${ }^{1}$, Juana Cecilia Trujillo-Reyes ${ }^{2} \&$ Mariam M. Magdy ${ }^{3}$ \\ ${ }^{1}$ Auburn University at Montgomery, Alabama, USA \\ ${ }^{2}$ Universidad de las Américas Puebla, Mexico \\ ${ }^{3}$ German University in Cairo, Egypt \\ Correspondence: Tarek A. El Badawy, Auburn University at Montgomery, Alabama, USA. E-mail: \\ tarek.elbadawy@aum.edu
}

Received: January 4, 2017

Accepted: January 22, 2017

Online Published: January 27, 2017

doi:10.5430/bmr.v6n1p28

URL: http://dx.doi.org/10.5430/bmr.v6n1p28

\begin{abstract}
The aim of this study was to examine the effect of several demographic variables on organizational culture, organizational citizenship behavior and job satisfaction. This comparative study extracted two samples from Egypt (127 participants) and Mexico (116 participants). Participants answered a 7-point Likert scale questionnaire and SPSS software was used to analyze the data. Results showed no demographic effect on the three constructs. From Egypt, differences were only observed on the managerial level regarding the market organizational culture. Results also showed significant results from Mexico on the managerial level and job satisfaction, organizational citizenship behavior, and clan and adhocracy organizational cultures. Further implications and future research directions are provided.
\end{abstract}

Keywords: Organizational culture, Organizational citizenship behavior, Job satisfaction, Egypt, Mexico, Comparative study, Demographic

\section{Introduction}

"Cultures are a natural outgrowth of the social interactions that make up what we call organizations" (Trice \& Beyer, 1993 cited in Mohanty \& Rath, 2012, p. 67). Organizational culture is the set of shared ideologies, philosophies, values, behaviors, attitudes and norms in an organization (Balay \& Ipek, 2010). Organizational cultures can be a competitive edge if they aided organizations in effectively dealing with external environmental changes, maintaining internal consistency (Ubius \& Alas, 2009) and strengthening employee's commitment (O'Reilly, 1989). Additionally, Cameron and Quinn (2005) reported that successful organizations are those which have strong consistent cultures that are easily identifiable. They also reached the conclusion that cultures have direct significant effects on performance and effectiveness.

The organizational culture affects a spectrum of organizational variables. For example, a positive association was found between employee's attitudes such as job satisfaction and organizational culture (e.g. Harris \& Mossholder, 1996; Odom et al., 1990; Zavyalova \& Kucherov, 2010). The relationship specifically heightens when the culture helps employees make decisions, improve their skills, and work in teams (Griffin, Patterson, \& West, 2001; Park \& Kim, 2009).

Job satisfaction is all the positive emotional feelings that result from the evaluation of an employee's responsibilities in the organization. It can be used to evaluate working conditions. Satisfaction can be related not only to the job but also to dimensions related to the job such as remuneration, supervisors and morale (Wharton, Rotolo, \& Bird, 2000; Dormann \& Zapf, 2001; Volkwein \& Zhou, 2003; Lee \& Liu, 2007; Park \& Kim, 2009).

Organizational culture and organizational citizenship behavior (OCB) are positively associated as well (Mohanty \& Rath, 2012). The concept of organizational citizenship behavior is defined as all the behaviors that are informal, performed by employees, and exceed the required task and duties. Those behaviors will neither be rewarded nor compensated but they are beneficial for the work group as they will support the social and psychological environment of the organization (Vigoda-Gadot, 2007; Boerner, Dutschke, \& Wied, 2008; Tang et al., 2008). 
Successful organizational cultures encourage OCB and acknowledge individual employee acts. OCB enhances the smooth flow of an organization's operations, increases productivity and decreases the amount of resources used due to careful and efficient use (Coyne \& Ong, 2007; Rego et al., 2010). OCB helps managers and co-workers to perform more effectively and reduces interpersonal conflicts that cause distractions (Boerner et al., 2008; Bolino \& Turnley, 2005; Messer \& White, 2006; Ryan, 2002; Tang et al., 2008).

The associations between the three constructs are established and repeatedly investigated by scholars. Nevertheless, the effect of the demographic variables on those constructs is under researched. Despite the existence of several studies as will be explained in the literature, further investigations are required to validate the current research available.

In the present study, an attempt was made to examine the effect of five demographic variables on organizational culture, organizational citizenship behavior, and job satisfaction. Two samples were extracted from Egypt and Mexico to analyse the interactions.

The following sections provide an overview on organizational culture, organizational citizenship behavior and job satisfaction. Next, the research on demographics and organizational constructs will be explored. Then, the research questions, methodology and results are provided. The paper ends with discussion, limitations and future research considerations.

\section{Literature Review}

\subsection{Organizational Culture}

Organizational cultures arise from the employees whose interactions together create rites, rituals, common language and, in some cases, an informal code of conduct is developed that can support or hinder the organization's managerial goals. Organizational cultures can be a competitive edge when they allow employees and employers to deal effectively with external challenges, maintain internal co-ordination (Ubius \& Alas, 2009) and strengthen employee commitment (O'Reilly, 1989). Additionally, Cameron and Quinn (2005) reported that successful organizations are those which have strong consistent cultures that are easily identifiable.

Wallach (1983) identified three separate organizational cultures, namely bureaucratic, innovative, and supportive. However, it was Cameron and Freeman (1991) who developed the famous typology of organizational cultures (four types of cultures). The market culture is concerned with external stakeholders focusing on competitiveness and productivity (Ubius \& Alas, 2009). The hierarchy culture is very formal and well organized. It enhances the stability, predictability, and the internal efficiency of the company. This culture is characterized by having strict internal control policies as it emphasizes rules and regulations that clarify what needs to be done (Ubius \& Alas, 2009).

The adhocracy culture is about being flexible, accepting change and adapting to it. Recruiters in this type of organizational culture seek innovators (Ubius \& Alas, 2009). Moreover, Conrad et al. (1997) mentioned that the adhocracy cultures are the second most effective type of culture after the market culture.

Finally, the clan culture is characterized by having a strong and rigid internal control system, however, with a degree of flexibility. This type of culture is very famous in family-owned businesses. The clan culture promotes teamwork, wide-sharing discussions, and job involvement (Ubius \& Alas, 2009). Nevertheless, the four types are not mutually exclusive; an organization can have traces of more than one type at the same time.

\subsubsection{Culture and Different Organizational Variables}

Job satisfaction, organizational citizenship behavior, commitment, motivation and leadership are among few of the variables associated with the features of organizational cultures. Empirical research on organizational culture indicates positive correlations with job performance (Shahzad et al., 2013), leadership behaviors (Tsai, 2011), and effectiveness (Gregory et al., 2009). Azanza et al. (2013) reported that flexible organizational cultures yield higher rates of job satisfaction. Waris (2005) provided evidence that there is a positive relationship between the market type of culture and employee job satisfaction.

Waris (2005) found positive correlation between the market culture and OCB. In addition, he provided support to the claim that job satisfaction acts as a moderator between culture and OCB; the indirect relationship was significantly positive.

\subsection{Organizational Citizenship Behavior (OCB)}

"OCB is work-related actions beyond the formal job description but vastly appreciated by workforce, for the reason that it can boost the efficiency and achievability of organizational goals" (Organ, 1988, cited in Batool, 2013, p. 647). In other words, OCB is an intrinsic attitude; it is neither considered for rewards, bonuses nor performance appraisals. 
OCB can be studied from the perspective of the organization as a whole or of certain individuals (Blakely et al., 2003; Ehrhart, 2004; Lavelle et al., 2009).

Coyne and Ong (2007) identified five main dimensions of OCB: Altruism, courtesy, sportsmanship, conscientiousness and civic virtue. Altruism focuses on activities that help others in work-related problems. Courtesy activities aim to help prevent problems for other employees. Sportsmanship activities try to bear problems and avoid taking actions to handle a complaint. Individuals with conscientiousness respect and follow rules and regulations, are efficient in time and exceed expectations in performance. Finally, civic virtue is participating in activities related to the organization's benefit (Dipaolo \& Hoy, 2005; Chu et al., 2006; Vigoda-Gadot, 2007; Rego et al., 2010).

OCB was conceptualized from a number of sources. Katz (1964) described it as activities dedicated to help colleagues, actions to protect the organizational system, self-development to improve the organization's operations and externally focused activities to support the organization's reputation. OCB is an American construct. It developed from western cultures, similar to most of the organizational behavior variables known today. However, it is not known whether the concept is culture-versatile (Farh et al., 2004). In the Japanese culture, for example, little research has been done on $\mathrm{OCB}$ as many of the Asian cultures are collectivist and employees consider their organizations as family. Hence, employees follow orders without thinking whether the tasks they are doing are part of their job description (Ueda, 2012). Farh et al. (2004) investigated OCB in China. Results showed five other dimensions that were more culture-related. They were self-training, social welfare participation, saving company's resources, keeping the workplace clean, and maintaining interpersonal harmony.

Mohanty and Rath (2012) investigated the relationship between organizational culture and OCB in three different industries. Their results showed significant positive correlations between all facets of organizational culture and OCB. Despite the differences between the organizations, the correlations were significantly positive and this was attributed to the strong prevailing cultures in the investigated organizations that make employees conform and hence, engage in OCB. Particularly, support (facet of culture) scored the highest correlation with civic virtue (facet of OCB) with $\mathrm{r}=0.62(\mathrm{p}<0.01)$.

The practical importance of OCB is that it improves organizational efficiency and effectiveness by contributing to resource transformations, creativity, and adaptability (Williams \& Anderson, 1991, cited in Bonaparte Jr., 2008). Although OCB is not formally recognized, research has shown that contextual performance does affect performance appraisals and rewards the same as task performance. For example, in the army, it was found that contextual performance affected the distribution of rewards (medals and promotions) (Van Scotter et al., 2000).

\subsection{Job Satisfaction (JS)}

JS emphasizes the specific task environment in which an employee performs his or her duties (Mowday et al., 1982). JS is conceptualized in three ways: Intrinsic, extrinsic, and total satisfaction (Weiss et al., 1967). Locke (1976) defined job satisfaction as a positive emotional state that results from appraising one's job. Job satisfaction can be related to different facets of the job including pay, supervisors and morale (Dormann \& Zapf, 2001; Lee \& Liu, 2007; Park \& Kim, 2009).

Lund (2003) examined the relationship between organizational culture and job satisfaction in American marketing professionals. His results showed that clan and adhocracy cultures have significant higher levels of job satisfaction as opposed to market and hierarchy cultures. However, Shurbagi and Zahari (2012) found significant positive relationship between all organizational cultures and job satisfaction.

Zavyalova and Kucherov (2010) found that organizations with market and hierarchic cultures showed average job satisfaction with scores of 4.0 and 4.7, respectively. As for the clan and adhocracy cultures, higher levels of job satisfaction with a score of 5.2 were reported. Thus, the satisfaction is higher in organizations characterized as being innovative and supportive rather than hierarchical cultures.

Abbaspour and Noghreh (2015) also reported significant positive correlation between organizational culture and job satisfaction. In addition, in their Iranian sample, organizational culture explained $50.4 \%$ of the variance in job satisfaction. Several scholars also confirmed the relation (Roodt et al., 2002; Jill et al., 2003; Navaie-Waliser et al., 2004; Arnold \& Spell, 2006; Chang \& Lee, 2007; Nayak \& Barik, 2013). Belias et al. (2015) found that culture partially predicated job satisfaction in a sample of Greek employees working in the banking sector. In particular, researchers found that adhocracy and market types of cultures lead to dissatisfaction and they attributed this to the economic state of the country.

Studies also correlated job satisfaction with OCB, suggesting that job satisfaction is an antecedent to OCB (Alotaibi, 2001; Kuehn \& Al-Busaidi, 2002; LePine et al., 2002; Murphy et al., 2002; Waris, 2005). Islam et al. (2014) reported 
that perceived organizational support and a learning organization culture both positively influence job satisfaction. In addition, a learning organization culture affected OCB (specifically towards the organization) positively.

Swaminathan and Jawahar (2013) found a positive relationship between job satisfaction and organizational citizenship behavior especially the help-oriented behaviors. The positive correlation was also supported by Jena and Goswami (2013) who showed that satisfaction with work ranked first, followed by satisfaction with supervisors, satisfaction with co-workers, satisfaction with promotion, and satisfaction with pay respectively.

\subsection{Organizational Variables: The Demographics Effect}

Demographic variables are extensively discussed in relation to different organizational variables. The premises of such assumptions are based on Hofstede's argument that there are relative disparities between individuals and groups. For example, gender affects organizational culture due to the differences in perceptions and the possible existence of treatment differentials between males and females in different contexts.

Rajput and Kochhar (2014) studied the effect of demographics on several organizational variables in a sample of faculty members. Gender, age, occupation and type of organization affected responses with respect to motivation, values and the intention to remain with the organization. In contrast, marital status affected responses on intention to stay and values only.

Age, gender, education level, managerial level, and organization tenure are all potential predictors of organizational commitment, job satisfaction (Mathieu \& Zajac, 1990) and leadership outcomes (Walumbwa et al., 2008). Riordan, Griffith, and Weatherly (2003) suggested that employees with longer tenure or are older are more likely to become emotionally attached to their organizations. In addition, older employees were found to be more satisfied with their jobs than younger employees (Herzberg et al., 1957; Rhodes, 1983).

With respect to knowledge sharing, in a sample from Central Europe, Grubić-Nešić et al. (2015) concluded that gender, education level, and tenure affected knowledge sharing. However, age and years of experience did not have an effect.

With respect to culture, using Hofstede's model and demographics in a sample from the film industry, Peterson (2014) found that age and years of experience had no effect on the participant response, unlike gender and the education level, which had some effect. A film crew has a culture of creativity and team-orientation, making the dynamics of culture harder to identify and outline. However, Paul (2012) studied the interaction between the different bureaucratic orientations of organizational culture and job satisfaction. The results showed some disparity with regard to gender. However, education level did not have an effect on the variables.

Sempane et al.'s (2002) research on job satisfaction and organizational culture added gender as a demographic, and found no significant difference with respect to it. Romaine (1999) found no direct correlation between organizational cultures and gender.

With respect to job satisfaction, in a sample of banking employees in Pakistan, it was found that age did not affect job satisfaction. The researchers attributed this to the satisfactory benefits offered by the bank that made age irrelevant to job satisfaction. However, the same study showed that gender affected job satisfaction as males were more satisfied than female employees. The researchers attributed the results to the culture of the organization as women face many barriers including glass-ceiling and stigmatization (Khan et al., 2013). Age was also reported to have an effect on job satisfaction in a sample of Turkish teachers (Yucel \& Bektas, 2012). On the other hand, in a hierarchical culture, gender did not have a significant impact on job satisfaction (Nixon, 2013).

Mauno et al. (2012) studied the effect of gender in family-owned organizations in Finland. Results showed that women benefited more from family support and had higher job satisfaction levels than men. Such results coincide with Ubius and Alas's discussion on clan culture (2009). Evans (2012) found no significant correlations between gender and education level with job satisfaction and perceived performance in non-profit organizations.

Al-Hussami (2008) conducted a study on nurses' job satisfaction using the level of education. The results suggested a relationship between job satisfaction and level of education. Clark and Oswald (1996) reported in their study that highly educated individuals have lower levels of job satisfaction.

Wofford (2003) reported positive correlation between age and job satisfaction, positive correlation between tenure and job satisfaction and higher levels of job satisfaction for employees in managerial levels. However, there was no difference in job satisfaction with respect to gender.

Huang et al. (2015) studied the interaction between age and OCB. Younger employees reported higher OCB as a form of impression management. However, older employees engage in OCB for pro-social motives. Moreover, in a 
sample of college students, females were more inclined to show OCB than males (LeBlanc, 2014). Aiming to study the effect of demographics on OCB, Noble (2006) found significant relationship between the level of education and the OCB dimension of civic virtue. However, gender did not have an effect on OCB.

Based on previous findings of the literature, the researchers aimed to explore the effect of demographics on the three variables of organizational culture, organizational citizenship behavior and job satisfaction. Accordingly, the research questions for this study were:

RQ1: What is the effect of gender on organizational culture, job satisfaction and organizational citizenship behavior in the Egyptian and Mexican samples?

RQ2: What is the effect of age on organizational culture, job satisfaction and organizational citizenship behavior in the Egyptian and Mexican samples?

RQ3: What is the effect of years of experience on organizational culture, job satisfaction and organizational citizenship behavior in the Egyptian and Mexican samples?

RQ4: What is the effect of education level on organizational culture, job satisfaction and organizational citizenship behavior, in the Egyptian and Mexican samples?

RQ5: What is the effect of managerial level on organizational culture, job satisfaction and organizational citizenship behavior in the Egyptian and Mexican samples?

\section{Method}

\subsection{Participant and Procedure}

The study was based on two samples. The first sample was 127 Egyptian employees who were MBA candidates and the second sample contained 116 Mexican employees, also studying for their MBA degrees. All participants worked in private service and manufacturing organizations.

For the Egyptian sample, $63 \%$ were males and $37 \%$ females. The majority of the sample was between 25 and 30 years old (33.9\%); $26.8 \%$ were $31-35$ years old, $21.3 \%$ were $36-40$ years old, $19 \%$ were older than 40 years and $6.3 \%$ younger than 25 years old. Regarding education, $82.5 \%$ held bachelor degrees. For experience, $39.4 \%$ had $5-10$ years of experience, $33.1 \%$ had less than 5 years of experience and $18.9 \%$ had $11-15$ years of experience. Finally, 38.6\% were middle management, $30 \%$ held non-managerial positions, $21.3 \%$ were first-line managers and $10 \%$ were top management.

Half of the Mexican sample were males. The majority of the sample was between 25-30 years old (44.8\%); $25.9 \%$ were 31-35 years old, $12.1 \%$ below 25 years old and $17 \%$ above 35 years old. Master degrees were held by $66.4 \%$ of the sample. Regarding years of experience, $44.7 \%$ had fewer than 5 years of experience, $28.1 \%$ had 5-10 years of experience and $15 \%$ had $11-15$ years of experience. Finally, $47.4 \%$ were middle management, $20.2 \%$ were first-line managers and $18.4 \%$ were top management as opposed to $14 \%$ holding non-managerial positions.

\subsection{Instrument Used}

The distributed questionnaire constituted of three distinct instruments each measuring one of the study's variables as will be explained below. The final version of the questionnaire contained fifty-one items.

\section{Organizational Culture}

A 24-item Organizational Culture Assessment Instrument (OCAI) was used. This tool measures culture in terms of six characteristics for each culture type. The questions were measured using a seven-point Likert scale (Worley, 2010).

\section{Organizational Citizenship Behavior}

A 17-item tool that measures the five dimensions of OCB as classified by Coyne and Ong (2007) was adopted. The questions were measured using seven-point Likert scale.

\section{Job satisfaction}

A 5-item tool was used. The questions were measured using seven-point Likert scale in which 1 represented strongly disagree and 7 strongly agree (Judge et al., 1998).

\subsection{Analysis}

Comparisons of means were conducted using SPSS software for the statistical analysis. 


\section{Results}

Table 1. Effect of Gender

\begin{tabular}{|c|c|c|c|c|c|c|c|c|c|c|}
\hline \multicolumn{11}{|c|}{ Egypt } \\
\hline & Gender & $\mathrm{N}$ & Mean & $\begin{array}{c}\text { Std. } \\
\text { Deviation }\end{array}$ & $\begin{array}{c}\text { Std. } \\
\text { Error } \\
\text { Mean }\end{array}$ & $\begin{array}{c}\text { Mean } \\
\text { Difference }\end{array}$ & $\begin{array}{l}\text { Std. Error } \\
\text { Difference }\end{array}$ & $\mathrm{t}$ & $\mathrm{df}$ & Probability \\
\hline \multirow{2}{*}{ JS } & Male & 80 & 4.78 & 0.99 & 0.11 & \multirow{2}{*}{0.13} & \multirow{2}{*}{0.18} & \multirow{2}{*}{0.68} & \multirow{2}{*}{125} & \multirow{2}{*}{0.49467} \\
\hline & Female & 47 & 4.65 & 1.03 & 0.15 & & & & & \\
\hline \multirow{2}{*}{ OCB } & Male & 80 & 5.45 & 0.67 & 0.07 & \multirow{2}{*}{0.05} & \multirow{2}{*}{0.12} & \multirow{2}{*}{0.46} & \multirow{2}{*}{125} & \multirow{2}{*}{0.64393} \\
\hline & Female & 47 & 5.40 & 0.60 & 0.09 & & & & & \\
\hline \multirow{2}{*}{ Hierarchy } & Male & 80 & 4.42 & 1.14 & 0.13 & \multirow{2}{*}{0.23} & \multirow{2}{*}{0.22} & \multirow{2}{*}{1.05} & \multirow{2}{*}{125} & \multirow{2}{*}{0.29694} \\
\hline & Female & 47 & 4.20 & 1.26 & 0.18 & & & & & \\
\hline \multirow{2}{*}{ Clan } & Male & 80 & 4.51 & 1.29 & 0.14 & \multirow{2}{*}{0.19} & \multirow{2}{*}{0.25} & \multirow{2}{*}{0.78} & \multirow{2}{*}{125} & \multirow{2}{*}{0.43570} \\
\hline & Female & 47 & 4.31 & 1.45 & 0.21 & & & & & \\
\hline \multirow{2}{*}{ Adhocracy } & Male & 80 & 4.31 & 1.28 & 0.14 & \multirow{2}{*}{0.40} & \multirow{2}{*}{0.24} & \multirow{2}{*}{1.63} & \multirow{2}{*}{125} & 010500 \\
\hline & Female & 47 & 3.91 & 1.41 & 0.21 & & & & & 0.1030 \\
\hline Morket & Male & 80 & 4.61 & 1.07 & 0.12 & 010 & (2) & 0.98 & 125 & (0) 32661 \\
\hline MIAI Ket & Female & 47 & 4.41 & 1.06 & 0.16 & 0.19 & 0.20 & 0.90 & $12 J$ & 0.52001 \\
\hline & & & & & & & & & & \\
\hline & Gender & $\mathrm{N}$ & Mean & $\begin{array}{c}\text { Std. } \\
\text { Deviation }\end{array}$ & $\begin{array}{c}\text { Std. } \\
\text { Error } \\
\text { Mean }\end{array}$ & $\begin{array}{c}\text { Mean } \\
\text { Difference }\end{array}$ & $\begin{array}{l}\text { Std. Error } \\
\text { Difference }\end{array}$ & $\mathrm{t}$ & df & Probability \\
\hline IS & Male & 59 & 5.31 & 1.16 & 0.15 & 000 & 020 & 047 & 114 & 063810 \\
\hline JS & Female & 57 & 5.22 & 0.94 & 0.12 & 0.09 & 0.20 & 0.41 & 114 & 0.05019 \\
\hline $\mathrm{OCP}$ & Male & 59 & 5.74 & 0.76 & 0.10 & 003 & 012 & 021 & 114 & 082340 \\
\hline CD & Female & 57 & 5.77 & 0.52 & 0.07 & -0.05 & 0.12 & -0.21 & 114 & 0.0354 \\
\hline Hierarchy & Male & 59 & 5.37 & 1.07 & 0.14 & -005 & 017 & -032 & 114 & 074967 \\
\hline 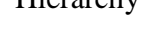 & Female & 57 & 5.42 & 0.73 & 0.10 & $-0.0 J$ & 0.17 & -0.02 & 114 & 0.14301 \\
\hline Clan & Male & 59 & 5.20 & 1.20 & 0.16 & 012 & 021 & 0.57 & 114 & 0.56936 \\
\hline clan & Female & 57 & 5.08 & 1.09 & 0.14 & 0.12 & 0.21 & 0.01 & 114 & 0.50030 \\
\hline$\Delta d$ brocy & Male & 59 & 5.14 & 1.25 & 0.16 & 00 & ב? & 040 & 114 & 068686 \\
\hline Aunocracy & Female & 57 & 5.05 & 1.16 & 0.15 & 0.09 & 0.22 & 0.40 & 114 & 0.00000 \\
\hline & Male & 59 & 5.47 & 1.10 & 0.14 & 016 & (20 0 & 078 & 114 & 012957 \\
\hline Market & Female & 57 & 5.31 & 1.08 & 0.14 & 0.10 & 0.20 & 0.18 & 114 & $0.4583 /$ \\
\hline
\end{tabular}

To answer the first research question, the effect of gender on the three variables was explored. As shown in Table 1, gender had no effect on any of the variables in both Egyptian and Mexican samples ( $p>0.05)$.

To answer the second research question, age was analyzed on three intervals only (less than 30, 30-35 and above 35 years old). It was concluded that age did not have an effect on the three variables similar to gender $(p>0.05)$ in Egypt and Mexico.

To answer the third research question, the effect of years of experience was investigated in the same manner as gender and age. Intervals were reduced to less than five years, 5-10 years, and more than ten years. Years of experience did not have an effect on the participants' answers regarding the three variables $(p>0.05)$ in Egypt and Mexico.

Regarding the level of education (RQ4), the answers were combined under two categories: bachelor degree holders and postgraduate degree holders. It was concluded that the level of education did not affect the responses of participants on the three variables ( $p>0.05$ ) in Egypt and Mexico.

Finally, the effect of the managerial level was explored for both samples (RQ5). 
Table 2. Effect of Managerial Level

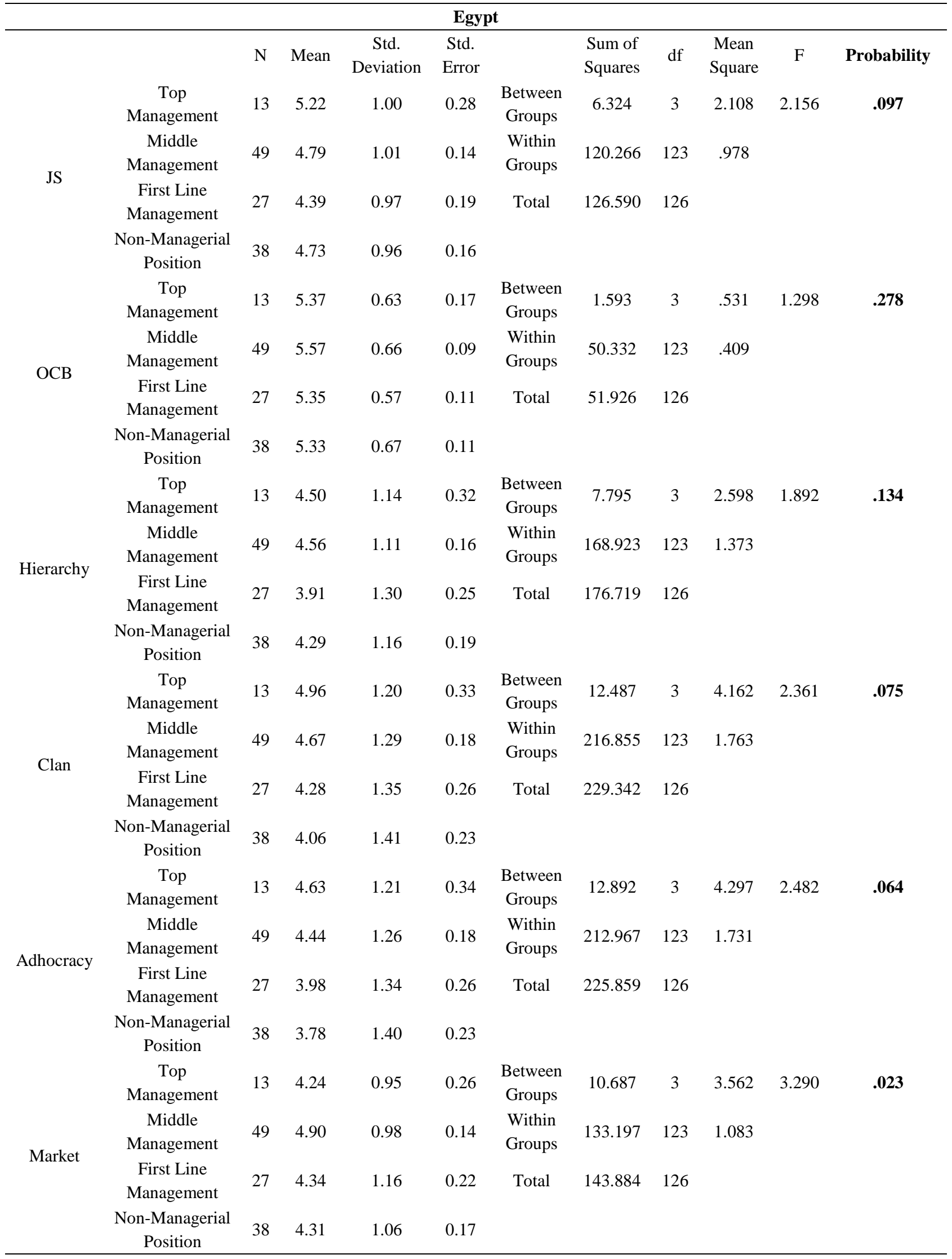




\begin{tabular}{|c|c|c|c|c|c|c|c|c|c|c|c|}
\hline \multicolumn{12}{|c|}{ Mexico } \\
\hline \multirow{5}{*}{ JS } & & $\mathrm{N}$ & Mean & $\begin{array}{c}\text { Std. } \\
\text { Deviation }\end{array}$ & $\begin{array}{l}\text { Std. } \\
\text { Error }\end{array}$ & & $\begin{array}{l}\text { Sum of } \\
\text { Squares }\end{array}$ & $\mathrm{df}$ & $\begin{array}{l}\text { Mean } \\
\text { Square }\end{array}$ & $\mathrm{F}$ & Probability \\
\hline & $\begin{array}{c}\text { Top } \\
\text { Management }\end{array}$ & 21 & 5.40 & 1.28 & 0.28 & $\begin{array}{l}\text { Between } \\
\text { Groups }\end{array}$ & 9.760 & 3 & 3.253 & 3.258 & .024 \\
\hline & $\begin{array}{c}\text { Middle } \\
\text { Management }\end{array}$ & 54 & 5.31 & 0.91 & 0.12 & $\begin{array}{l}\text { Within } \\
\text { Groups }\end{array}$ & 109.835 & 110 & .998 & & \\
\hline & $\begin{array}{c}\text { First Line } \\
\text { Management }\end{array}$ & 23 & 5.57 & 0.94 & 0.20 & Total & 119.595 & 113 & & & \\
\hline & $\begin{array}{c}\text { Non-Managerial } \\
\text { Position }\end{array}$ & 16 & 4.59 & 0.97 & 0.24 & & & & & & \\
\hline \multirow{4}{*}{ OCB } & $\begin{array}{c}\text { Top } \\
\text { Management }\end{array}$ & 21 & 5.61 & 0.94 & 0.21 & $\begin{array}{l}\text { Between } \\
\text { Groups }\end{array}$ & 3.524 & 3 & 1.175 & 2.861 & .040 \\
\hline & $\begin{array}{c}\text { Middle } \\
\text { Management }\end{array}$ & 54 & 5.84 & 0.54 & 0.07 & $\begin{array}{l}\text { Within } \\
\text { Groups }\end{array}$ & 45.164 & 110 & .411 & & \\
\hline & $\begin{array}{c}\text { First Line } \\
\text { Management }\end{array}$ & 23 & 5.95 & 0.52 & 0.11 & Total & 48.688 & 113 & & & \\
\hline & $\begin{array}{c}\text { Non-Managerial } \\
\text { Position }\end{array}$ & 16 & 5.42 & 0.62 & 0.16 & & & & & & \\
\hline \multirow{4}{*}{ Hierarchy } & $\begin{array}{c}\text { Top } \\
\text { Management }\end{array}$ & 21 & 5.13 & 1.20 & 0.26 & $\begin{array}{l}\text { Between } \\
\text { Groups }\end{array}$ & 4.627 & 3 & 1.542 & 2.005 & .118 \\
\hline & $\begin{array}{c}\text { Middle } \\
\text { Management }\end{array}$ & 54 & 5.51 & 0.76 & 0.10 & $\begin{array}{l}\text { Within } \\
\text { Groups }\end{array}$ & 84.638 & 110 & .769 & & \\
\hline & $\begin{array}{c}\text { First Line } \\
\text { Management }\end{array}$ & 23 & 5.67 & 0.80 & 0.17 & Total & 89.266 & 113 & & & \\
\hline & $\begin{array}{c}\text { Non-Managerial } \\
\text { Position }\end{array}$ & 16 & 5.18 & 0.87 & 0.22 & & & & & & \\
\hline \multirow{4}{*}{ Clan } & $\begin{array}{c}\text { Top } \\
\text { Management }\end{array}$ & 21 & 5.10 & 1.36 & 0.30 & $\begin{array}{l}\text { Between } \\
\text { Groups }\end{array}$ & 14.546 & 3 & 4.849 & 3.986 & .010 \\
\hline & $\begin{array}{c}\text { Middle } \\
\text { Management }\end{array}$ & 54 & 5.31 & 0.84 & 0.11 & $\begin{array}{l}\text { Within } \\
\text { Groups }\end{array}$ & 133.802 & 110 & 1.216 & & \\
\hline & $\begin{array}{c}\text { First Line } \\
\text { Management }\end{array}$ & 23 & 5.42 & 1.04 & 0.22 & Total & 148.348 & 113 & & & \\
\hline & $\begin{array}{c}\text { Non-Managerial } \\
\text { Position }\end{array}$ & 16 & 4.30 & 1.55 & 0.39 & & & & & & \\
\hline \multirow{4}{*}{ Adhocracy } & $\begin{array}{c}\text { Top } \\
\text { Management }\end{array}$ & 21 & 4.96 & 1.25 & 0.27 & $\begin{array}{l}\text { Between } \\
\text { Groups }\end{array}$ & 12.496 & 3 & 4.165 & 3.012 & .033 \\
\hline & $\begin{array}{c}\text { Middle } \\
\text { Management }\end{array}$ & 54 & 5.27 & 1.06 & 0.14 & $\begin{array}{l}\text { Within } \\
\text { Groups }\end{array}$ & 152.114 & 110 & 1.383 & & \\
\hline & $\begin{array}{c}\text { First Line } \\
\text { Management }\end{array}$ & 23 & 5.28 & 1.11 & 0.23 & Total & 164.610 & 113 & & & \\
\hline & $\begin{array}{c}\text { Non-Managerial } \\
\text { Position }\end{array}$ & 16 & 4.31 & 1.51 & 0.38 & & & & & & \\
\hline \multirow{4}{*}{ Market } & $\begin{array}{c}\text { Top } \\
\text { Management }\end{array}$ & 21 & 5.26 & 1.10 & 0.24 & $\begin{array}{l}\text { Between } \\
\text { Groups }\end{array}$ & 8.108 & 3 & 2.703 & 2.409 & .071 \\
\hline & $\begin{array}{c}\text { Middle } \\
\text { Management }\end{array}$ & 54 & 5.56 & 0.88 & 0.12 & $\begin{array}{l}\text { Within } \\
\text { Groups }\end{array}$ & 123.418 & 110 & 1.122 & & \\
\hline & $\begin{array}{c}\text { First Line } \\
\text { Management }\end{array}$ & 23 & 5.59 & 1.15 & 0.24 & Total & 131.526 & 113 & & & \\
\hline & $\begin{array}{c}\text { Non-Managerial } \\
\text { Position }\end{array}$ & 16 & 4.81 & 1.39 & 0.35 & & & & & & \\
\hline
\end{tabular}


As shown in Table 2, managerial levels did affect the responses in the Egyptian sample concerning the market culture only. However, for the Mexican sample, the results were significant $(\mathrm{p}<0.05)$ for job satisfaction, OCB, and clan and adhocracy types of cultures.

For the market culture, from the Egyptian sample, the mean levels were close in value. Nevertheless, the middle management reported the highest average score followed by first-line management.

For job satisfaction, Mexican first-line managers reported the highest average level of job satisfaction followed by top management and middle management respectively. For OCB, Mexican first-line managers also reported the highest average level of OCB engagement followed by middle management and then top management.

For the types of cultures, Mexican first-line managers had the highest average in clan culture followed by middle management. For the adhocracy type of culture, first and middle management levels reported almost the same average score.

\section{Discussion}

The present study was explorative in nature. The aim was to analyze the effect of the demographic variables on the three constructs, organizational culture, organizational citizenship behavior and job satisfaction in two samples, from Egypt and Mexico.

The conceptualization of organizational culture was based on Cameron and Freeman's typology of culture (market, hierarchy, adhocracy and clan). The average scores reported by participants for all culture types were higher in Mexico than in Egypt. Regarding OCB, the results also showed that the overall OCB was higher in Mexico than in Egypt, specifically acts of sportsmanship, consciousness and civic virtue. Such results suggest that organizational cultures are stronger in Mexican organizations where employees naturally relate and conform to their respective cultures. Accordingly, and consistent with the previous literature (Alotaibi, 2001; Kuehn \& Al-Busaidi, 2002; LePine et al., 2002; Murphy et al., 2002; Waris, 2005; Jena \& Goswami, 2013), the average level of job satisfaction was higher in Mexico than in Egypt.

In the attempt to answer the five research questions, the effect of the demographic variables (gender, age, years of experience, education level and managerial level) on organizational culture, organizational citizenship behavior and job satisfaction was explored. There were no significant effects for gender, age, and years of experience and education levels in both of the Egyptian and Mexican samples. Noble (2006) and Wofford (2003) reported no effect of gender on OCB and JS as well.

However, for the managerial levels, the results were mixed. The Egyptian sample reported insignificant effect except for the market culture. For the Mexican sample, the managerial level (specifically first and middle levels of management) had a significant effect on the clan and adhocracy types of cultures. These results are consistent with previous literature and with the characteristics of the two types of cultures. The clan culture reflects the perfect balance between control and flexibility while adhocracy reflects innovativeness and constant need for change (Ubius \& Alas, 2009). Hence, employees in lower levels of management, who are typically eager to explore, open-minded, and motivated to learn are congruent with these two types of cultures.

For job satisfaction, first-line managers reported the highest average level of job satisfaction followed by top and middle management, respectively. The results coincide with Woffod (2003) who reported higher levels of JS for employees in managerial levels.

For OCB, first-line management also reported the highest average level of OCB engagement followed by middle and then top management. These results also provide support to the notion that lower levels of management have room to generate change inside their organizations to improve effectiveness and efficiency (Williams \& Anderson, 1991 cited in Bonaparte Jr., 2008). Accordingly, they strongly identify with their organizations leading to higher levels of OCB, and consequently, higher job satisfaction.

\section{Limitations and Future Research Recommendations}

The study had several limitations. The sample size was relatively small in relation to the whole population. This was due to the context of the sample (employees taking MBA classes) which limited the number of participants and time-confined the data collection procedure. In addition, the sample did not cover all cities in both countries nor all industries. Third, the insignificance of the results suggests that the sample composition was not heterogeneous. Forth, using different instruments tailored for each country might have provided different results. Finally, the research instrument focused on the organizational culture in both countries with no reference to the national culture and its interaction effect. 
Future studies should focus on bigger sample sizes, different industries and different countries. Further investigations of the effects of demographics on culture, OCB and JS are required. Future studies could also turn to observations and qualitative methods to gain in-depth data about the behavior of employees and consider the national culture where values and norms are conceived.

\section{Conclusion}

Despite the fact that the majority of the results were insignificant, research on the effect of demographics is still rare and insufficient to make generalized and global conclusions. In this study, the researchers attempted to study the effect of five demographic variables in two samples from Egypt and Mexico.

Managers can utilize the results of this study to focus on their organizational cultures. Managers should be aware of the importance of a strong consistent culture that is easily identifiable. Human resource practitioners inside organizations should search for areas of deficiency in their employee cultural orientations.

Managers should also be interested in eliciting advice from their employees (across different age ranges and managerial levels) on what makes them motivated and satisfied and what obstacles are hindering them from performing well. In addition, contextual performance should be monitored and awarded in the right moment to encourage employees to engage in citizenship behaviors that serve the organization.

\section{References}

Abbaspour, A. \& Noghreh, A. (2015). Examine the relationship between organizational culture and job satisfaction of tourism bank employees in Iran. International Journal of Academic Research, 7(1), 63-68.

Al-Hussami, M. (2008). A study of nurses' job satisfaction: The relationship to organizational commitment, perceived organizational support, transactional leadership, transformable leadership, and level of education. European Journal of Scientific Research, 22(2), 286-295.

Alotaibi, A.G. (2001). Antecedents of organizational citizenship behavior: A study of public personnel in Kuwait Public Personnel Management, 30(3), 363-376.

Arnold, T. \& Spell, C. S. (2006). The relationship between justice and benefits satisfaction. Journal of Business and Psychology, 20(4), 599-620. https://doi.org/10.1007/s10869-005-9006-1

Azanza, G., Moriano, J.A. \& Molero, F. (2013). Authentic leadership and organizational culture as drivers of employees' job satisfaction. Journal of Work and Organizational Psychology, 29, 45-50. https://doi.org/10.5093/tr2013a7

Balay, R., \& İpek, C. (2010). Teachers' perception of organizational culture and organizational commitment in Turkish primary schools. Journal of World of Turks, 2(1), 363-384.

Batool, S. (2013). Developing organizational commitment and organizational justice to amplify organizational citizenship behavior in banking sector. Pakistan Journal of Commerce and Social Sciences, 7(3), 646-655.

Belias, D., Koustelios, A., Vairaktarakis, G. \& Sdrolias, L. (2015). Organizational culture and job satisfaction of Greek banking institutions. Procedia - Social and Behavioral Sciences, 175, 314-323. https://doi.org/10.1016/j.sbspro.2015.01.1206

Blakely, G. L., Andrews, M. C. \& Fuller, J. (2003). Are Chameleons good citizens? A longitudinal study of the relationship between self-monitoring and organizational citizenship behavior. Journal of Business and Psychology, 18(2), 131-144. https://doi.org/10.1023/A:1027388729390

Boerner, S., Dutschke, E. \& Wied, S. (2008). Charismatic leadership and organizational citizenship behavior: Examining the role of stressors and strain. Human Resource Development International, 11(5), 507-521. https://doi.org/10.1080/13678860802417643

Bolino, M. C. \& Turnley, W.H. (2005). The personal costs of citizenship behavior: The relationship between individual initiative and role overload, job stress, and work-family conflict. Journal of Applied Psychology, 90(4), 740-748. https://doi.org/10.1037/0021-9010.90.4.740

Bonaparte Jr., W. (2008). The impact of organizational citizenship behavior and organizational commitment on organizational performance'. PhD Thesis, H. Wayne Huizenga School of Business and Entrepreneurship. Nova Southeastern University, Florida, United States of America.

Cameron, K. S. \& Quinn, R. E. (2005). Diagnosing and changing organizational culture: Based on the competing values framework. John Wiley \& Sons. 
Cameron, K.S. \& Freeman, S.J. (1991). Cultural congruence, strength and type: Relationships to effectiveness. Research in Organizational Change and Development, 5, 23-58.

Chang, S. C. \& Lee, M. S. (2007). A study on relationship among leadership, organizational culture, the operation of learning organization and employees' job satisfaction. The learning organization, 14(2), 155-185. https://doi.org/10.1108/09696470710727014

Chu, C.-I., Lee, M.-S. \& Hsu, H.-M. (2006). The impact of social support and job stress on public health nurses' organizational citizenship behaviors in rural Taiwan. Public Health Nursing, 23(6), 496-505. https://doi.org/10.1111/j.1525-1446.2006.00599.x

Clark, A. E., \& Oswald, A. J. (1996). Satisfaction and comparison income. Journal of Public Economics, 61(3), 359-381. https://doi.org/10.1016/0047-2727(95)01564-7

Conrad, C., Brown, G. \& Harmon, H. (1997). Customer satisfaction and corporate culture: A profile deviation analysis of a relationship marketing outcome. Psychology and Marketing, 14(7), 663-674. https://doi.org/10.1002/(SICI)1520-6793(199710)14:7<663::AID-MAR2>3.0.CO;2-E

Coyne, I. \& Ong, T. (2007). Organizational citizenship behavior and turnover intention: A cross-cultural study. International Journal of Human Resource Management, 18(6), 1085-1097. https://doi.org/10.1080/09585190701321831

Dipaolo, M., \& Hoy, W. (2005). Organizational Citizenship of Faculty and Achievement of High School Students. The High School Journal, 88(3), 35-44. https://doi.org/10.1353/hsj.2005.0002

Dormann, C., \& Zapf, D. (2001). Job satisfaction: A meta-analysis of stabilities. Journal of Organizational Behavior, 22(5), 483-504. https://doi.org/10.1002/job.98

Ehrhart, M. G. (2004). Leadership and procedural justice climate as antecedents of unit-level organizational citizenship behavior. Personnel Psychology, 57, 61-94. https://doi.org/10.1111/j.1744-6570.2004.tb02484.x

Evans, A. H. (2012). Self-efficacy, job satisfaction and demographic variables in a non-profit organization. $\mathrm{PhD}$ Thesis. Capella University.

Farh, J., Zhong, C. \& Organ, D. (2004). Organizational citizenship behavior in the people's Republic of China. Organization Science, 15(2), 241-253. https://doi.org/10.1287/orsc.1030.0051

Gregory, B. T., Harris, S. G., Armenakis, A. A. \& Shook, C. L. (2009). Organizational culture and effectiveness: A study of values, attitudes, and organizational outcomes. Journal of Business Research, 62(7), 673-679. https://doi.org/10.1016/j.jbusres.2008.05.021

Griffin, M. A., Patterson, M. G. \& West, M. A. (2001). Job Satisfaction and teamwork: The role of supervisor support. Journal of Organizational Behavior, 22(5), 537-550. https://doi.org/10.1002/job.101

Grubić-Nešić, L., Matić, D. \& Mitrović, S. (2015). The influence of demographic and organizational factors on knowledge sharing among employees in organizations. Tehnicki vjesnik/Technical Gazette, 22(4), 1005-1010. https://doi.org/10.17559/TV-20141216213746

Harris, S. G. \& Mossholder, K. W. (1996). The affective implications of perceived congruence with culture dimensions during organizational transformation. Journal of Management, 22, 527-547. https://doi.org/10.1177/014920639602200401

Herzberg, F., Mausner, B., Peterson, R.O. \& Capwell, D.F. (1957). Job Attitudes: Review of Research and Opinion, Oxford, England: Psychological Service of Pittsburgh.

Huang, Y., McDowell, J. \& Vargas, P. (2015). How old I feel matters: Examining age-related differences in motives and organizational citizenship behavior. Journal of Park and Recreation Administration, 33(1), 20-39.

Islam, T., Khan, S., Ahmad, U.N.U. \& Ahmed, I. (2014). Exploring the relationship between POS, OLC, job satisfaction and OCB. Procedia - Social and Behavioral Sciences, 114, 164-169. https://doi.org/10.1016/j.sbspro.2013.12.678

Jena, R. K. \& Goswami, R. (2013). Exploring the relationship between organizational citizenship behavior and job satisfaction among shift workers in India. Global Business and Organizational Excellence, 32(6), 36-46. https://doi.org/10.1002/joe.21513 
Jill, A. W. C. W. C., McKinnon, L. \& Harrison, G. L. (2003). Organizational cultural: Association with commitment, job satisfaction, propensity to remain, and information sharing in Taiwan. Journal of Development Studies, 39(6), 1-22.

Judge, T. A., Locke, E. A., Durham, C. C. \& Kluger, A. N. (1998). Dispositional effects on job and life satisfaction: The role of core evaluations. Journal of Applied Psychology, 83(1), 17-37. https://doi.org/10.1037/0021-9010.83.1.17

Katz, D. (1964). The motivational basis of organizational behavior. Behavioral Science, 9, 131-146. https://doi.org/10.1002/bs.3830090206

Khan, A., Ramzan, M. \& Butt, M. S. (2013). Is job satisfaction of Islamic banks operational staff determined through organizational climate, occupational stress, age and gender. Journal of Business Studies Quarterly, 4(3), 13-26.

Kuehn, K.W. \& Al-Busaidi, Y. (2002). Citizenship behavior in a non-Western context: An examination of the role of satisfaction, commitment, and job characteristics on self-reported OCB. International Journal of Commerce and Management, 12(2), 107-126. https://doi.org/10.1108/eb047446

Lavelle, J. J., Brockn, J., Konovsky, M. A., Price, K. H., Henlry, A. B., Taneja, A., \& Vinekar, V. (2009). 'Commitment, procedural fairness, and organizational citizenship behavior: A multifoci analysis. Journal of Organizational Behavior, 30, 337-357. https://doi.org/10.1002/job.518

LeBlanc, C. J. (2014). Characteristics shaping college student organizational citizenship behavior. American Journal of Business Education, 7(2), 99-108. https://doi.org/10.19030/ajbe.v7i2.8468

Lee, H. \& Liu, C. (2007). An examination of factors affecting repatriates' turnover intentions. International Journal of Manpower, 28(2), 122-134. https://doi.org/10.1108/01437720710747956

LePine, J. A., Erez, A. \& Johnson, D. E. (2002). The nature and dimensionality of organizational citizenship behavior: A critical review and meta-analysis. Journal of Applied Psychology, 87(1), 52-65. https://doi.org/10.1037/0021-9010.87.1.52

Locke, E. A. (1976). The nature and causes of job satisfaction. Handbook of Industrial and Organizational Psychology, 1, 1297-1343.

Lund, D.B. (2003). Organizational culture and job satisfaction. Journal of Business and Industrial Marketing, 18(3), 219-236. https://doi.org/10.1108/0885862031047313

Mathieu, J. E. \& Zajac, D. M. (1990). A review and meta-analysis of the antecedents, correlates, and consequences of organizational commitment. Psychological Bulletin, 108, 171-194. https://doi.org/10.1037/0033-2909.108.2.171

Mauno, S., Kinnunen, U. \& Feldt, T. (2012). Work-family culture and job satisfaction: Does gender and parenting status alter the relationship?. Community, Work \& Family, 15(1), 101-129. https://doi.org/10.1080/13668803.2011.598733

Messer, B. A. E. \& White, F. A. (2006). Employees' mood, perceptions of fairness, and organizational citizenship behavior. Journal of Business and Psychology, 21(1), 65-82. https://doi.org/10.1007/s10869-005-9018-x

Mohanty, J. \& Rath, B.P. (2012). Influence of organizational culture on organizational citizenship behavior: A three-sector study. Global Journal of Business Research, 6(1), 65-76.

Mowday, R. T., Porter, L. W. \& Steers, R. M. (1982). Employee Organization Linkages: The Psychology of Commitment, Absenteeism, and Turnover, New York: Academic Press.

Murphy, G., Athanasou, J. \& King, N. (2002). Job satisfaction and organizational citizenship behavior: A study of Australian human service professional. Journal of Managerial Psychology, 17(4), 287-298. https://doi.org/10.1108/02683940210428092

Navaie-Waliser, M., Lincoln, P., Karuturi, M. \& Reisch, K. (2004). Increasing job satisfaction, quality care, and coordination in home health. Journal of Nursing Administration, 34(2), 88-92. https://doi.org/10.1097/00005110-200402000-00007

Nayak, B. \& Barik, A. (2013). Assessment of the link between Organizational culture and job satisfaction (Study of an Indian Public Sector). Business and Management, 5(4), 47-61.

Nixon, M. (2013). Organizational behavior: Gender and its relationship to employee job satisfaction within the department of the army. $\mathrm{PhD}$ Thesis. Capella University. 
Noble, D. A. (2006). The relationship of formal education and gender to organizational citizenship behaviors. $\mathrm{PhD}$ Thesis. Argosy University/Sarasota, Florida.

Odom, R. Y. Boxx, W. R. \& Dunn, M. G. (1990). Organizational culture, commitment, satisfaction, and cohesion. Public Productivity and Management Review, 14(2), 157-179. https://doi.org/10.2307/3380963

O'Reilly, C. (1989). Corporations, culture, and commitment: Motivation and social control in organizations. California Management Review, 31(4), 9-25. https://doi.org/10.2307/41166580

Park, J. S. \& Kim, T. H. (2009). Do types of organizational culture matter in nurse job satisfaction and turnover intention?, Leadership in Health Services, 22(1), 20-38. https://doi.org/10.1108/17511870910928001

Paul, M.E. (2012). Organizational culture and employees' job satisfaction as mitigated by gender, level of education, and longevity in a bureaucratic oriented culture. $\mathrm{PhD}$ Thesis. Capella Univeristy.

Peterson, L. C. (2014). That's a wrap! The organizational culture and characteristics of successful film crews. Journal of Organizational Culture, Communications and Conflict, 18(1), 89-114.

Rajput, N. \& Kochhar, R. (2014). Demographic factors: Organizational culture in the academic institutions. SCMS Journal of Indian Management, 11(3), 51-63.

Rego, A., Ribeiro, N. \& Cunha, M. P. (2010). Perceptions of organizational virtuousness and happiness as predictors of organizational citizenship behaviors. Journal of Business Ethics, 93, 215-235. https://doi.org/10.1007/s10551-009-0197-7

Rhodes, S. R. (1983). Age-related differences in work attitudes and behavior: A review and conceptual analysis. Psychological Bulletin, 93, 323-367. https://doi.org/10.1037/0033-2909.93.2.328

Riordan, C. M., Griffith, R. W. \& Weatherly, E. W. (2003). Age and work-related outcomes: The moderating effects of status characteristics. Journal of Applied Social Psychology, 33(1), 37-57. https://doi.org/10.1111/j.1559-1816.2003.tb02072.x

Romaine, J. (1999). The influence of organizational culture and gender salience on managers' decision-making style. PhD Thesis. McMaster University, Hamilton, ON, Canada.

Roodt, G., Rieger, H. S. \& Sempane, M. E. (2002). Job satisfaction in relation to organisational culture. SA Journal of industrial Psychology, 28(2), 23-30.

Ryan, J. J. (2002). Work values and organizational citizenship behaviors: Values that work for employees and organizations. Journal of Business and Psychology, 17(1), 123-132. https://doi.org/10.1023/A:1016246103190

Sempane, M.C., Rieger, H.S. \& Roodt, G. (2002). Job Satisfaction in relation to organizational culture. SA Journal of Industrial Psychology, 28(2), 23-30. https://doi.org/10.4102/sajip.v28i2.49

Shahzad, F., Iqbal, Z. \& Gulzar, M. (2013). Impact of organizational culture on employees job performance: An empirical study of software houses in Pakistan. Journal of Business Studies Quarterly, 5(2), 56-64.

Shurbagi, A. \& Zahari, I. (2012). The relationship between organizational culture and job satisfaction in national oil corporation of Libya. International Journal of Humanities and Applied sciences, 1(3), 88-93.

Swaminathan, S. \& Jawahar, P. D. (2013). Job satisfaction as a predictor of organizational citizenship behavior: An empirical study. Global Journal of Business Research, 7(1), 71-80.

Tang, T. T., Sutarso, T., Davis, G. M. W., Dolinski, D., Ibrahim, A. H. S., \& Wagner, S. L. (2008). To help or not to help? The good Samaritan effect and the love of money on helping behavior. Journal of Business Ethics, 82, 865-887. https://doi.org/10.1007/s10551-007-9598-7

Tsai, Y. (2011). Relationship between organizational culture, leadership behavior and job satisfaction. BMC health services research, 11(1), 98-106. https://doi.org/10.1186/1472-6963-11-98

Ubius, U. \& Alas, R. (2009). Organizational culture types as predictors of corporate social responsibility. Engineering Economics, 61(1), 90-99.

Ueda, Y. (2012). Effect of job involvement on importance evaluation of organizational citizenship behavior. International Journal of Business and Society, 13(1), 77-89.

Van Scotter, J., Motowidlo, S. J. \& Cross, T. C. (2000). Effects of task performance and contextual performance on systemic rewards. Journal of Applied Psychology, 8(4), 526-535. https://doi.org/10.1037/0021-9010.85.4.526 
Vigoda-Gadot, E. (2007). Redrawing the boundaries of OCB? An empirical examination of compulsory extra-role behavior in the workplace. Journal of Business and Psychology, 21(3), 377-405. https://doi.org/10.1007/s10869-006-9034-5

Volkwein, J. F., \& Zhou, Y. (2003). Testing a model of administrative job satisfaction. Research in Higher Education, 44(2), 149-171. https://doi.org/10.1023/A:1022099612036

Vukonjanski, J., Nikolić, M., Hadžić, O., Terek, E. \& Nedeljković, M. (2012). Relationship between GLOBE organizational culture dimensions, job satisfaction and leader-member exchange in Serbian organizations. Journal for East European Management Studies, 17(3), 333-368.

Wallach, E. J. (1983). Individuals and organizations: The cultural match. Training and Development Journal, 37(2), 29-36.

Walumbwa, F. O., Wu, C. \& Orwa, B. (2008). Contingent reward transactional leadership, work attitudes, and organizational citizenship behavior: The role of procedural justice climate perceptions and strength. Leadership Quarterly, 19, 251-265. https://doi.org/10.1016/j.leaqua.2008.03.004

Waris, R.G. (2005). An examination of organizational culture, employee attitudes, and organizational citizenship behavior: A path analysis approach. PhD Thesis, University of Missouri-Columbia, Kansas City, United States of America.

Weiss, D. J., Dawis, R. V. \& England, G. W. (1967). Manual for the Minnesota Satisfaction Questionnaire. Minnesota studies in vocational rehabilitation.

Wharton, A. S., Rotolo, T. \& Bird, S. R. (2000). Social context at work: A Multilevel analysis of job satisfaction. Sociological Forum, 15(1), 65-90. https://doi.org/10.1023/A:1007546120560

Wofford, T. D. (2003). A study of worker demographics and workplace job satisfaction for employees in a global engineering and construction organization. Doctor of Administration Thesis. Nova Southeastern University.

Worley, B. (2010). The Organizational Culture of Learfield Sports Properties. PhD Thesi., The University of North Carolina at Chapel Hill.

Yucel, I. \& Bektas, C. (2012). Job satisfaction, organizational commitment and demographic characteristics among teachers in Turkey: Younger is better?. Procedia - Social and Behavioral Sciences, 46, 1598-1608. https://doi.org/10.1016/j.sbspro.2012.05.346

Zavyalova, E., \& Kucherov, D. (2010). Relationship between organizational culture and job satisfaction in Russian business enterprises. Human Resource Development International, 13(2), 225-235. https://doi.org/10.1080/13678861003703740 